\title{
Induction of hypervascularity without leakage or inflammation in transgenic mice overexpressing hypoxia-inducible factor-1 $\alpha$
}

\author{
David A. Elson, ${ }^{1}$ Gavin Thurston, ${ }^{3,5}$ L. Eric Huang, ${ }^{6}$ David G. Ginzinger, ${ }^{1,2}$ Donald M. McDonald, ${ }^{3}$ \\ Randall S. Johnson, ${ }^{7}$ and Jeffrey M. Arbeit ${ }^{1,4,8}$ \\ ${ }^{1}$ Cancer Genetics Program and ${ }^{2}$ Genome Analysis Core Facility, UCSF Comprehensive Cancer Center, ${ }^{3}$ Department \\ of Anatomy and Cardiovascular Research Institute, and ${ }^{4}$ Department of Surgery, University of California, San Francisco, \\ San Francisco, California 94143, USA; ${ }^{5}$ Regeneron Pharmaceuticals, Inc., Tarrytown, New York 10591, USA; ${ }^{6}$ Laboratory \\ of Human Carcinogenesis, National Cancer Institute, National Institutes of Health, Bethesda, Maryland 20892-4255, USA; \\ ${ }^{7}$ Biology Department, University of California, San Diego, La Jolla, California 92093-0346, USA
}

\begin{abstract}
Hypoxia-inducible factor-1 $\alpha$ (HIF-1 $\alpha$ ) transactivates genes required for energy metabolism and tissue perfusion and is necessary for embryonic development and tumor explant growth. HIF-1 $\alpha$ is overexpressed during carcinogenesis, myocardial infarction, and wound healing; however, the biological consequences of HIF-1 $\alpha$ overexpression are unknown. Here, transgenic mice expressing constitutively active HIF-1 $\alpha$ in epidermis displayed a $66 \%$ increase in dermal capillaries, a 13 -fold elevation of total vascular endothelial growth factor (VEGF) expression, and a six- to ninefold induction of each VEGF isoform. Despite marked induction of hypervascularity, HIF-1 $\alpha$ did not induce edema, inflammation, or vascular leakage, phenotypes developing in transgenic mice overexpressing VEGF cDNA in skin. Remarkably, blood vessel leakage resistance induced by HIF-1 $\alpha$ overexpression was not caused by up-regulation of angiopoietin-1 or angiopoietin-2. Hypervascularity induced by HIF-1 $\alpha$ could improve therapy of tissue ischemia.
\end{abstract}

[Key Words: Hypoxia; HIF-1 $\alpha$; angiogenesis; skin; epidermis; keratin]

Received May 25, 2001; revised version accepted August 17, 2001.

Adaptation and survival in hypoxia hinge on the ability of cells to sense low oxygen concentration (Wenger 2000) and concomitantly increase expression of transcription factors that up-regulate multiple target genes (Semenza 1999, 2000). Hypoxia-inducible factor-1 (HIF-1) transactivates genes encoding several glucose transporters and glycolytic enzymes, as well as genes increasing tissue perfusion such as vascular endothelial growth factor $(V E G F)$, inducible nitric oxide synthase (iNOS), and erythropoietin (Semenza 1999). HIF-1 is a heterodimeric molecule composed of a labile $\alpha$ subunit (HIF-1 $\alpha$ ) and a constitutive $\beta$ subunit (HIF-1 $\beta$ /ARNT aryl hydrocarbon nuclear transporter). In normoxia, HIF- $1 \alpha$ protein is rapidly degraded via ubiquitination and proteasomal digestion. HIF- $1 \alpha$ degradation is mediated by a 200 -aminoacid oxygen-dependent degradation domain (ODD; Huang et al. 1998). Cells transfected with cDNA encoding HIF- $1 \alpha$ in which the ODD is deleted (HIF- $1 \alpha \Delta$ ODD) show constitutively active HIF- $1 \alpha$ protein regardless of oxygen tension (Huang et al. 1998).

HIF- $1 \alpha$ is required for both embryonic development and growth of tumor explants (Iyer et al. 1998; Ryan et al.

\footnotetext{
${ }^{8}$ Corresponding author.

E-MAIL jarbeit@cc.ucsf.edu; FAX (415) 476-8218.

Article and publication are at http://www.genesdev.org/cgi/doi/10.1101/ gad.914801.
}

1998), which underscores a central role of this molecule in the hypoxic response in vivo. In adult animals HIF-1 $\alpha$ is overexpressed in epithelial cancers and high-grade premalignant lesions (Zhong et al. 1998), ischemic cardiac muscle (Lee et al. 2000b), and healing wounds (Elson et al. 2000). As regulation of each of these conditions is complex, it is difficult to determine the mechanism by which HIF- $1 \alpha$ overexpression contributes to their pathophysiology. To dissect the function of HIF-1 $\alpha$ overexpression as a single molecular perturbation in vivo, we created transgenic mice overexpressing HIF- $1 \alpha$ in basal keratinocytes of skin and squamous epithelium (Arbeit 1996), using cDNAs encoding either wild-type HIF-1 $\alpha$ or the constitutively active mutant HIF-1 $\alpha \Delta$ ODD (Huang et al. 1998). We found that mice expressing HIF$1 \alpha \Delta$ ODD developed a microvasculature with biology distinct from that previously described for either VEGF or angiopoietin-1 and -2 .

Results

Copy number, transgene expression analysis, and identification of visible skin phenotype in HIF-1 $\alpha$ transgenic mice

Wild-type human HIF-1 $\alpha$ or HIF- $1 \alpha \Delta$ ODD cDNA (Huang et al. 1998) was cloned into the SmaI site of a 
keratin-14 expression vector (Fig. 1a) to guarantee that at least one form of the transgene would escape ubiquitination and protein degradation and be available to test gain of function. Microinjection into embryos of the $\mathrm{FVB} / \mathrm{n}$ in-bred strain produced eight K14-HIF-1 $\alpha$ and five K14-HIF- $1 \alpha \Delta$ ODD transgenic founder mice confirmed by PCR of tail DNA. Transgene copy number ranged from 2 to 20 in heterozygous founder mice /data not shown), and all subsequent work was performed in heterozygous transgenic mice and nontransgenic controls. RT-PCR analysis of total RNA from ear skin showed transgene expression in six HIF- $1 \alpha$ and all five HIF$1 \alpha \Delta$ ODD transgenic founders (data not shown). In situ hybridization revealed that transgene mRNA was appropriately targeted to basal keratinocytes of the interfollicular epidermis as well as the hair follicle outer root sheath, and confirmed that transgene expression was similar in mice containing either wild-type or HIF$1 \alpha \Delta$ ODD cDNA (Fig. 1d). Endogenous murine HIF-1 $\alpha$ was undetectable in nontransgenic skin (Elson et al. 2000 ). By $1-2$ mo of age, all five K14-HIF- $1 \alpha \Delta$ ODD transgenic founders developed a distinctive skin phenotype consisting of prominent reddening and vasculature of unfurred skin, including the ears (Fig. 1b, right panel), paws, and tails. In addition, the coat of truncal skin was roughened and uneven (Fig. 1b). Ears of each K14-HIF-1 $\alpha$

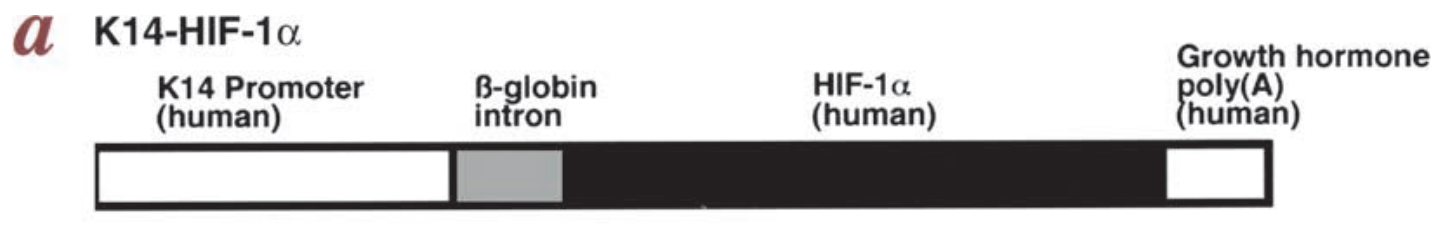

K14-HIF-1 $\alpha \Delta$ ODD

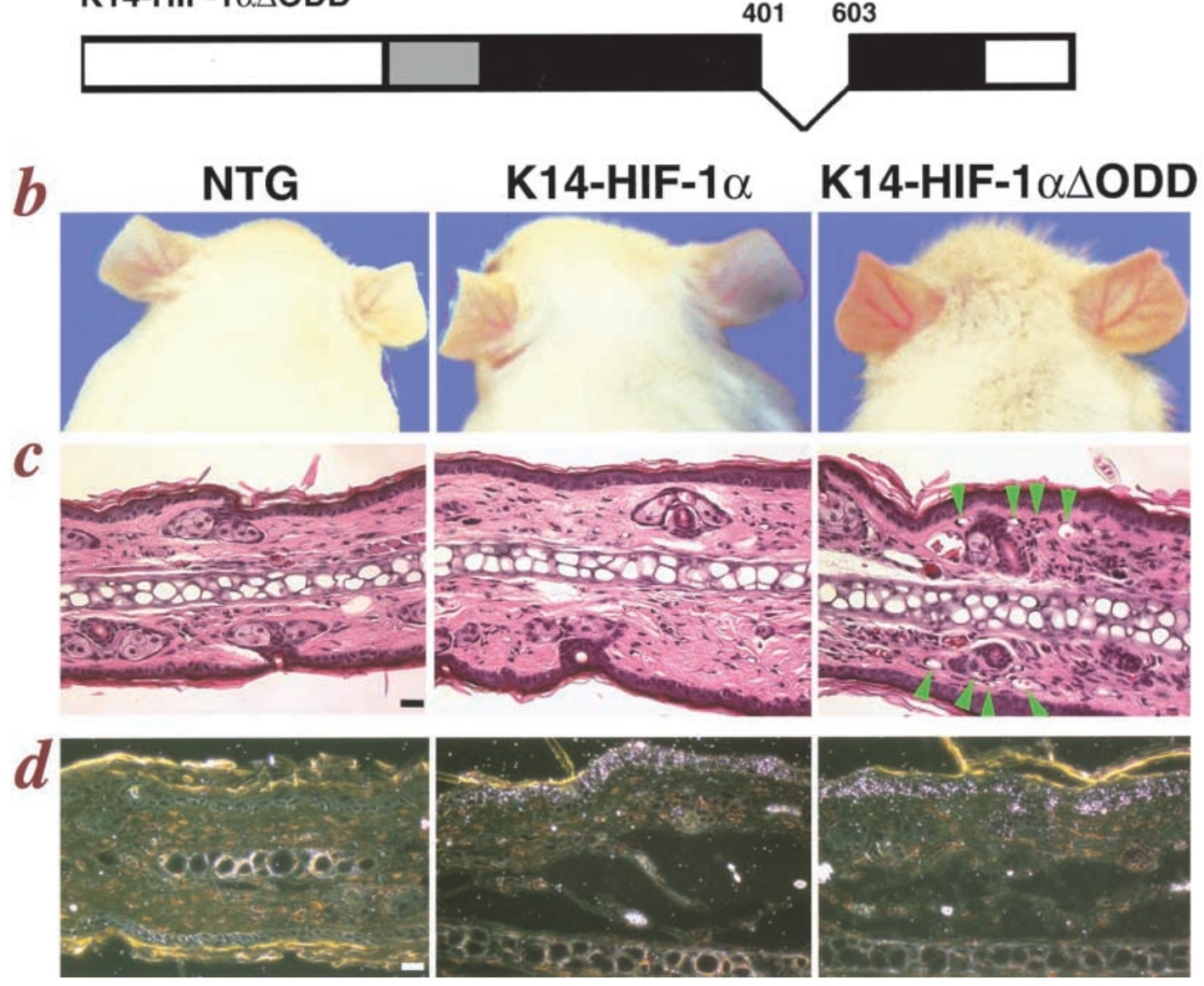

Figure 1. Generation and initial characterization of HIF-1 $\alpha$ transgenic mice. $(a)$ Constructs used to target wild-type human HIF-1 $\alpha$ or mutant HIF-1 $\alpha \Delta$ ODD (deletion of the oxygen-dependent degradation domain; Huang et al. 1998) to basal keratinocytes (Munz et al. 1999). Amino acids spanning the ODD are indicated. (b) Redness and prominent vasculature of ear skin and roughness of coat are evident in the K14-HIF-1 $\alpha \Delta$ ODD transgenic mice. K14-HIF-1 $\alpha$ transgenic mice are indistinguishable from nontransgenic controls. (c) Histopathology of ears reveals an increase in blood vessels (see green arrowheads) in the dermis of K14-HIF-1 $\alpha \Delta$ ODD transgenic mice. No inflammation or edema is detectable. (d) In situ hybridization with a ${ }^{35}$ S-labeled riboprobe specific for human HIF- $1 \alpha$. Both $H I F-1 \alpha$ and HIF-1 $\alpha \Delta O D D$ transgenes are expressed in basal keratinocytes of interfollicular epidermis and the hair follicle outer root sheath, and appear to be expressed at the same level, as visually estimated from silver grain density. Bars in $c$ and $d$ are $20 \mu \mathrm{m}$. 
transgenic founder mouse had the usual pink-white color of nontransgenic littermates (Fig. 1b, middle and left panels, respectively).

Three lines expressing mutant human HIF- $1 \alpha \Delta$ ODD derived from founder \#19, \#62, and \#71 that demonstrated similarly affected skin, and two lines expressing wild-type human HIF-1 $\alpha$, founder \#23 and \#49, were established based on the initial RT-PCR expression analysis. Subsequent quantitative RT-PCR using SYBR green detection revealed that transgene expression differences among the three lines varied according to \#19 > \#71 > \#62 (data not shown), which was similar to the copy number differences between these lines $(\sim 20,4$, and $1-2$, respectively). Subsequent work revealed a subtle difference in intensity of skin redness between the K14-HIF-1 $\alpha \Delta$ ODD transgenic lines. However, blood vessel biology defined by vascular density and blood vessel leakage resistance was similar in the three K14-HIF$1 \alpha \Delta$ ODD transgenic lines regardless of copy number and transgene expression level. The data have therefore been grouped according to genotype rather than individual mouse line for the majority of this study. Where appropriate, reference is made to distinctions between the HIF-1 $\alpha \Delta$ ODD transgenic lines. Mice transgenic with wild-type human HIF-1 $\alpha$ cDNA were analyzed together, as transgene expression was similar within these two established lines, and neither line displayed a visible or histological phenotype.

\section{Skin histopathology in HIF-1 $\alpha$ transgenic mice}

To further investigate the skin phenotype induced by HIF-1 $\alpha$ overexpression, we performed histopathological analysis of both furred and unfurred skin. Analysis of ear (Fig. 1c) and back skin (data not shown) from K14-HIF$1 \alpha \Delta$ ODD transgenic mice suggested an increased number of dermal blood vessels immediately below the epidermis and surrounding the hair follicles (see arrowheads in Fig. 1c). Neither edema nor inflammation was detectable in dermis or epidermis of K14-HIF- $1 \alpha \Delta$ ODD transgenic mice, and the epidermis itself was indistinguishable from that of nontransgenic mice (Fig. 1c). Lack of edema or inflammation in K14-HIF-1 $\alpha \Delta$ ODD transgenic mice was notable because VEGF, an HIF-1 target gene induced in these transgenic mice (Fig. 2), produces both pathologies when either the 164 or 120 isoform is overexpressed in basal keratinocytes of K14-VEGF164 or bovine K6-VEGF120 transgenic mice (Detmar et al. 1998; Larcher et al. 1998; Thurston et al. 1999).

To determine whether the skin phenotype induced by HIF- $1 \alpha$ overexpression progressed to more serious pathology than skin redness, groups of K14-HIF-1 $\alpha \Delta$ ODD and $\mathrm{K} 14-\mathrm{HIF}-1 \alpha$ transgenic mice and nontransgenic littermates were observed and serially sacrificed up to 18 mo of age. Although skin redness in the K14-HIF$1 \alpha \Delta$ ODD transgenic mice was greater by 2-3 mo of age, ulceration, angioma formation, or spontaneous skin tumor did not develop during more prolonged observation. K14-HIF- $1 \alpha$ transgenic mice remained phenotypically indistinguishable from nontransgenic littermates during the same duration of observation. In contrast, the skin phenotype of K14-VEGF164 transgenic mice was progressive such that spontaneous hemorrhagic ulcers developed in older mice (Thurston et al. 1999). It is also surprising that skin inflammation was not produced in K14-HIF- $1 \alpha \Delta$ DODD transgenic mice given the ability of

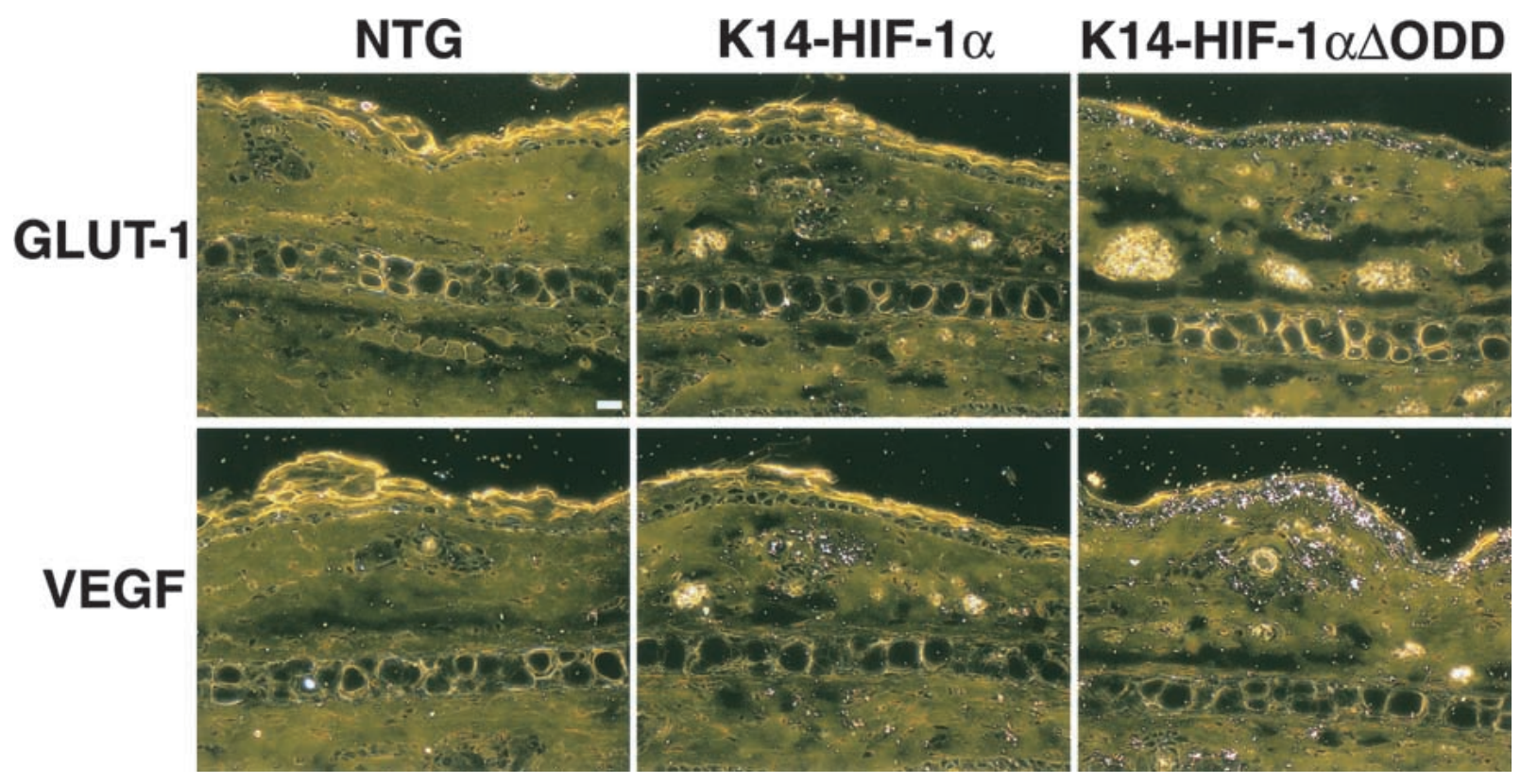

Figure 2. Expression of HIF-1 target genes. Glucose transporter-1 (GLUT-1) and vascular endothelial growth factor (VEGF) are expressed in both interfollicular epidermis and in the hair follicle outer root sheath of K14-HIF-1 $\alpha \Delta$ ODD transgenic mice. Low-level signals for both GLUT-1 and VEGF are present in the hair follicle outer root sheath of K14-HIF-1 $\alpha$ transgenic mice, whereas neither target gene is detectable in ear skin of nontransgenic mice. Bar, $20 \mu \mathrm{m}$. 
VEGF164 (see below) to increase leukocyte adherence and extravasation when overexpressed in skin (Detmar et al. 1998).

\section{In situ hybridization analysis of HIF-1 target gene expression}

Because the sequences of human and mouse HIF-1 $\alpha$ cDNAs are $>90 \%$ conserved at the amino acid level $/$ Semenza 1999|, we expected overexpression of the human protein to heterodimerize with endogenous HIF-1 $\beta$ / ARNT to form a functional HIF-1 transcription factor. To determine the transcriptional activity of HIF-1 produced in skin of K14-HIF-1 $\alpha \Delta$ ODD and K14-HIF- $1 \alpha$ transgenic mice, we investigated expression of two of its downstream targets, glucose transporter-1 (GLUT-1) and VEGF, using mRNA in situ hybridization. Both GLUT-1 and VEGF mRNA were easily detectable in both the interfollicular epidermis and hair follicles of K14-HIF$1 \alpha \Delta$ ODD transgenic mice (Fig. 2). In contrast, no VEGF or GLUT-1 expression was detectable in the interfollicular epidermis of transgenic mice overexpressing wildtype human HIF-1 $\alpha$ cDNA. Rather, low level signal for both HIF-1 targets was present in the hair follicles (Fig. 2). Hair follicles may be a niche where HIF-1 $\alpha$ protein is functional at low levels, because they are the site of cyclical proliferation controlled by paracrine growth factors (Gat et al. 1998), and wild-type HIF-1 $\alpha$ protein is stabilized by growth factor signaling in addition to hypoxia (Feldser et al. 1999). This low level induction of VEGF mRNA is insufficient to produce a hypervascular phenotype in the K14-HIF-1 $\alpha$ transgenic mice (Figs. 1b, 3a). Lack of expression of HIF-1 targets in nontransgenic skin is further evidence for the undetectable level of endogenous murine HIF- $1 \alpha$ activity in epidermis (Fig. 2). Strong induction of HIF-1 target genes underscores the use of the $\Delta$ ODD mutant compared with the wild-type cDNA as a means to bypass protein degradation and ensure gain of HIF-1 $\alpha$ function.

\section{Immunohistochemical analysis of blood vessel multiplicity}

The combination of reddened skin, histopathological evidence for angiogenesis, and induction of VEGF expression led us to further examine the extent of vascularization and the size and shape of blood vessels that developed in K14-HIF-1 $\alpha \Delta$ ODD transgenic mice compared with K14-HIF-1 $\alpha$ transgenic mice and nontransgenic controls. Immunohistochemistry with an antibody recognizing the endothelial marker CD31 highlighted the increase of dermal blood vessels immediately below the epidermis in the ears of K14-HIF- $1 \alpha \Delta$ ODD transgenic mice (Fig. 3a). Chalkley analysis of vascular density in ear skin (Chalkley 1943) revealed a statistically significant $30 \%$ increase in the number of blood vessels in the K14-HIF-1 $\alpha \Delta$ ODD transgenic mice compared with either the K14-HIF-1 $\alpha$ transgenic counterparts or nontransgenic controls, which were similar to each other (data not shown). To characterize blood vessel morphology and delineate blood vessel number and distribution in three dimensions, and to determine whether flow was present within individual vessels, we stained the vasculature of transgenic and nontransgenic mice by intravenous injection of biotinylated Lycopersicon esculentum lectin prior to perfusion-fixation. Low power views of ear skin whole mounts further showed the marked increase in number of perfused blood vessels in K14-HIF-1 $\alpha \Delta$ ODD transgenic mice compared with either K14-HIF-1 $\alpha$ counterparts or nontransgenic controls, which again were similar to each other (Fig. 3b). High power views revealed that blood vessels with a diameter and morphology consistent with capillaries were predominantly increased in the K14-HIF-1 $\alpha \Delta$ ODD transgenic mice, whereas the number and distribution of large caliber vessels appeared similar in all groups (Fig. 3b). Quantification of vascularity using a length-density algorithm (Thurston et al. 1999) revealed a 66\% increase in blood vessel length-density in all lines of K14-HIF$1 \alpha \Delta$ ODD transgenic mice compared with nontransgenic controls (Fig. 3c). Vessel length-density in K14-HIF-1 $\alpha$ transgenic mice was similar to nontransgenic controls. To investigate blood vessel multiplicity and distribution in back skin, K14-HIF-1 $\alpha \Delta$ ODD and nontransgenic mice were perfused with a fluorescein-labeled L. esculentum lectin, and thick frozen sections were used for microscopic analysis (Fig. 3d). Here, both interfollicular epidermis and hair follicles were extensively decorated with small caliber capillary-like blood vessels in the K14-HIF$1 \alpha \Delta$ ODD transgenic mice (Fig. $3 \mathrm{~d}$, right panel). In contrast, there were only occasional small caliber capillarylike blood vessels adjacent to hair follicles and only rare interfollicular blood vessels evident in the nontransgenic mice (Fig. 3d, left panel). Induction of an extensive microvasculature by HIF-1 $\alpha \Delta$ ODD was consistent with pronounced up-regulation of VEGF expression. However, capillaries developing in K14-HIF- $1 \alpha \Delta$ ODD transgenic mice were morphologically similar to those of nontransgenic mice. These microvessels lacked the tortuosity of microvasculature induced in vessels of mice overexpressing VEGF164 (Thurston et al. 1999) or the saccular morphology of vessels produced in transgenic mice overexpressing angiopoietin-1 (Suri et al. 1998).

\section{Determination of blood vessel permeability}

A hallmark of VEGF activity is its ability to increase blood vessel permeability (Dvorak et al. 1999). The inherent leakiness of the microvasculature of transgenic mice overexpressing either VEGF164 or VEGF120 is consistent with this VEGF function (Larcher et al. 1998; Thurston et al. 1999). As such, we expected blood vessel permeability to be similarly increased in K14-HIF$1 \alpha \Delta$ ODD transgenic mice, given the induction of VEGF mRNA by transgene expression (Fig. 2). Surprisingly, baseline vascular leakage in untreated K14-HIF$1 \alpha \Delta$ ODD transgenic mice was similar to that of nontransgenic controls following Evans blue dye injection (Fig. 4). Moreover, in response to inflammatory stimula- 
Elson et al.

$a$

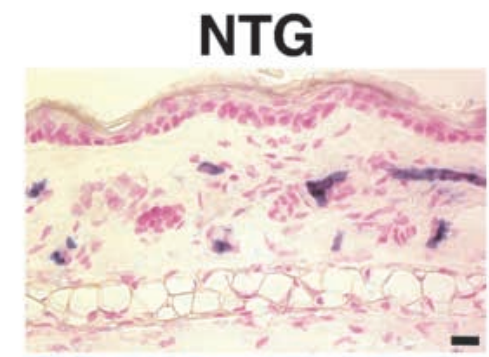

b
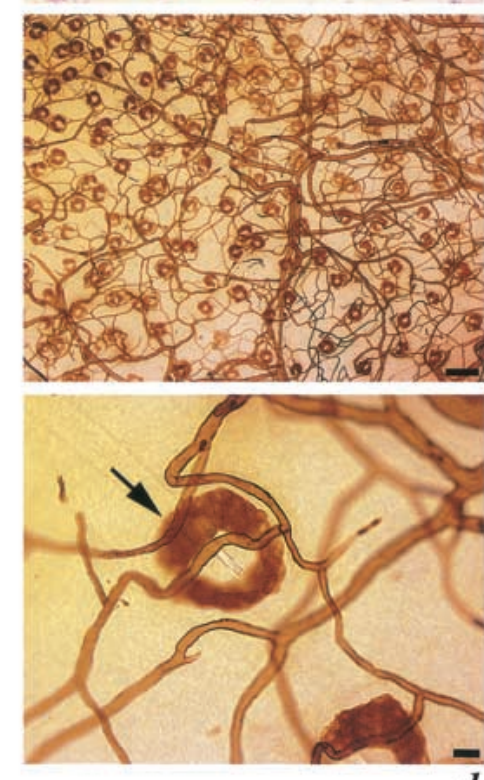

c

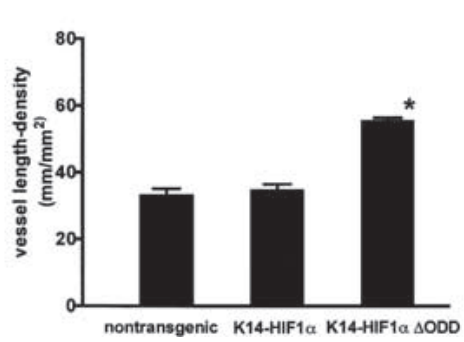

K14-HIF-1 $\alpha$
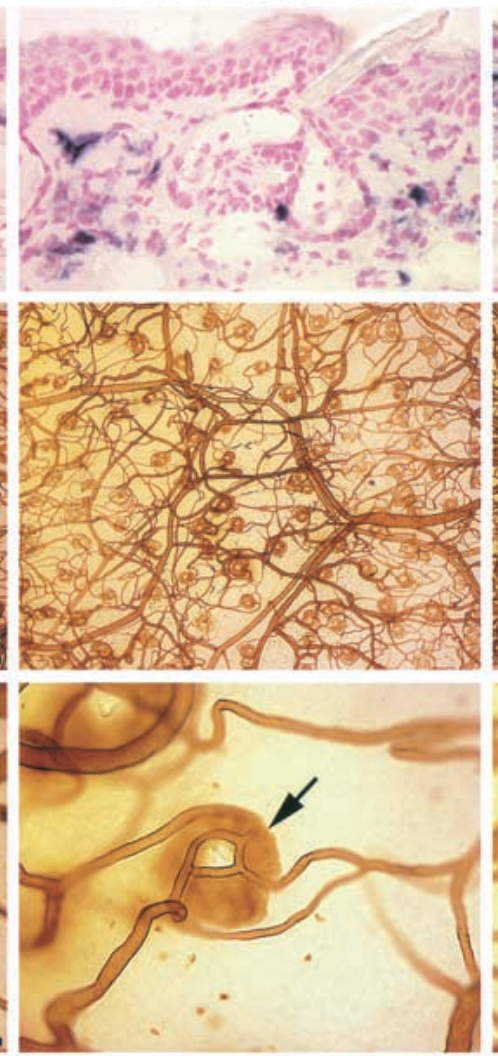

$d$

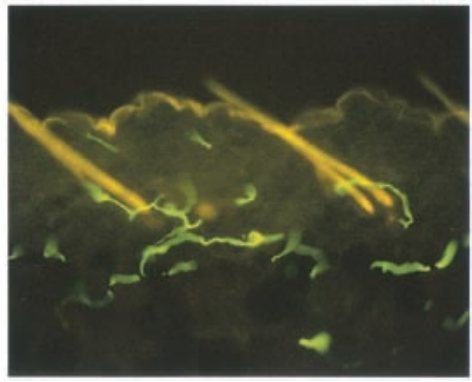

K14-HIF $\alpha \Delta$ ODD
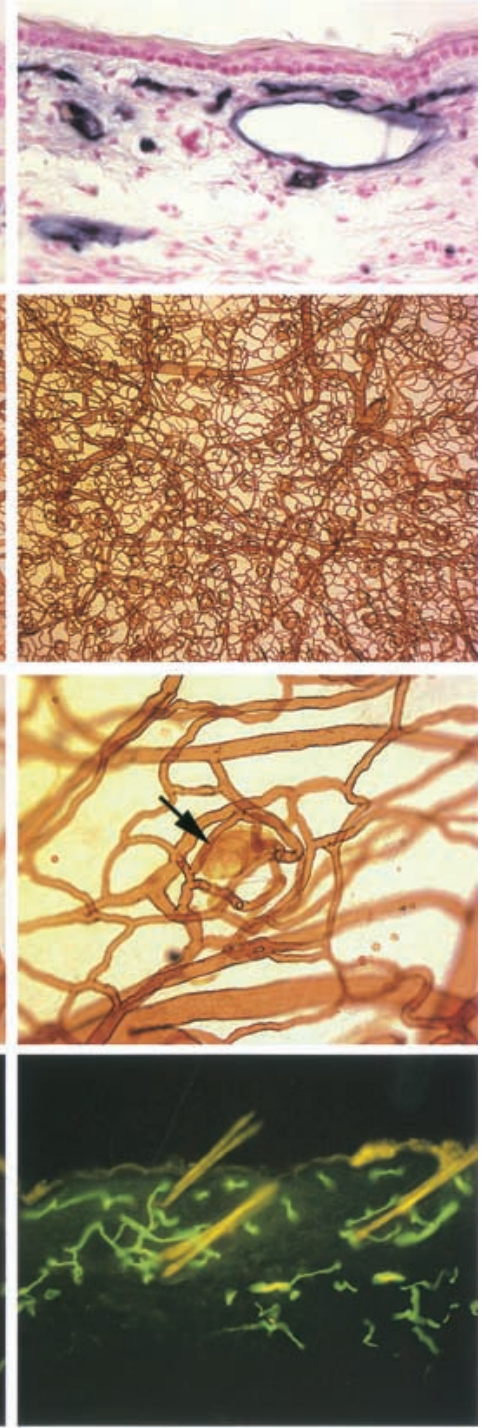

Figure 3. Blood vessel location, distribution, and permeability. (a) Immunohistochemistry for CD31 expression shows an increase in the number of dermal capillaries beneath the epidermis in the K14-HIF- $1 \alpha \Delta$ ODD compared with either the K14-HIF-1 $\alpha$ transgenic mice or nontransgenic controls. (b) Blood vessel morphology and multiplicity revealed by perfusion with biotinylated Lycopersicon esculentum lectin (Thurston et al. 1999). Low power views show the marked increase in blood vessel density in the K14-HIF-1 $\alpha \Delta$ ODD transgenic mice. High power views reveal that this increase is predominantly owing to an increase in capillaries with normal morphology. Capillaries and small caliber vessels are concentrically arranged around hair follicles in the K14-HIF-1 $\alpha \Delta$ ODD transgenic mice. The hair follicle sebaceous glands are peroxidase positive because of endogenous biotin (black arrows each lower panel in $b)$. $(c)$ Quantification of microvasculature vessel length-density (Thurston et al. 1999) from lectin-perfused ears confirm a $66 \%$ increase in blood vessel number in the K14-HIF- $1 \alpha \Delta$ ODD transgenic mice compared with either K14-HIF-1 $\alpha$ or nontransgenic mice $\left({ }^{\star} P<0.05\right.$, Mann-Whitney U test). Eight 10× fields from two to six mice of each genotype were counted. (d) Fluorescent lectin staining in thick sections shows that hair follicles and interfollicular epidermis in back skin of K14-HIF-1 $\alpha \Delta$ ODD transgenic mice (right panel) are decorated with small blood vessels, whereas nontransgenic back skin (left panel) contains only sporadic microvessels in the same locations. Bars, $a$ and lower line of $b, 20 \mu \mathrm{m}$; upper line of $b, 150 \mu \mathrm{m}$.

tion with topical mustard oil, skin vessels in K14-HIF$1 \alpha \Delta$ ODD transgenic mice displayed a modest but significantly lower level of blood vessel leakage compared with nontransgenic controls (Fig. 4b). In contrast, transgenic mice overexpressing VEGF164 displayed elevated vascular leakage at baseline that further increased following inflammatory stimuli (Thurston et al. 1999). The baseline and inflammatory vessel leakage in K14-HIF-1 $\alpha$ transgenic mice was similar to that in nontransgenic controls (data not shown). Therefore, despite induction of VEGF and an increase in microvascular density, HIF$1 \alpha$ overexpression produces a vasculature that is non- 
$a$

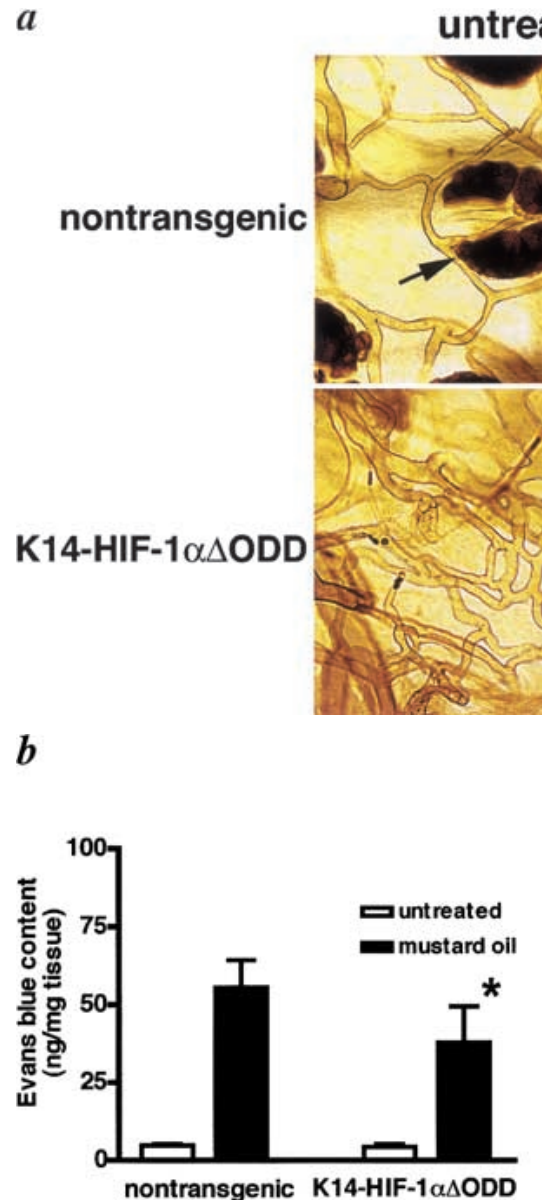

untreated

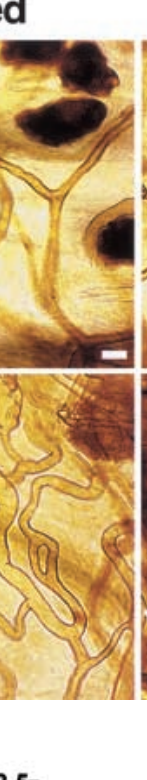

$c$ mustard oil

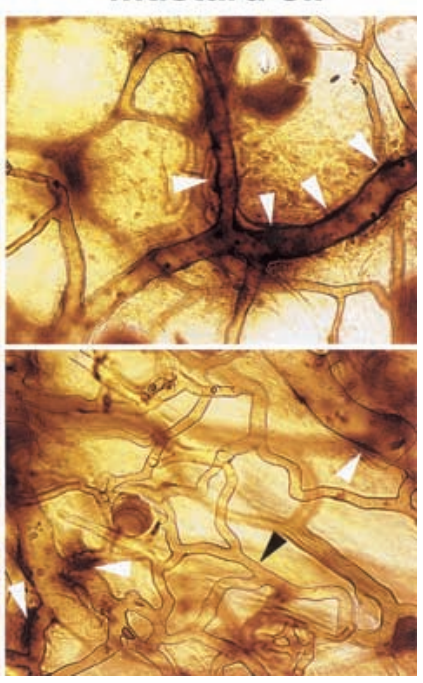

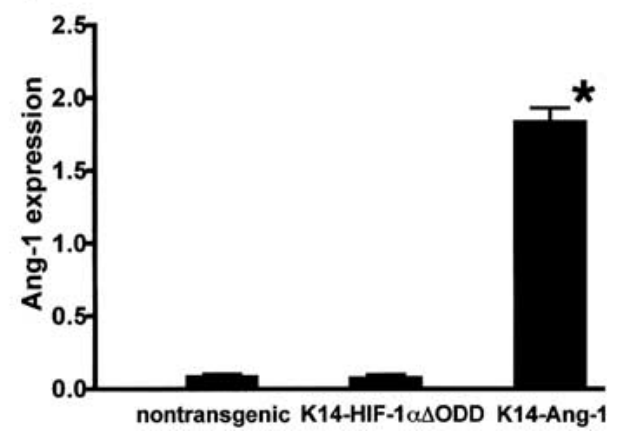

Figure 4. Determination of leakage sites and quantification of leak. (a) Mice were perfused with biotinylated Ricinus communis I lectin, which binds to endothelial basement membrane exposed at sites of vascular leakage (Thurston et al. 1996). Neither K14-HIF-1 $\alpha \Delta$ ODD nor nontransgenic mice evidence vascular leak at baseline (left upper and lower panels) despite blood vessel exposure to 6- to 10-fold elevations of VEGF and a marked increase in dermal capillaries in the K14-HIF$1 \alpha \Delta$ ODD transgenic mice. Following mustard oil application, sites of intense leakage are predominantly located at relatively large caliber postcapillary venules (white arrowheads) compared with capillary-like vessels (black arrowheads) in both the K14-HIF-1 $\alpha \Delta$ ODD transgenic mice and nontransgenic controls (right upper and lower panels). Leakage from postcapillary venules appeared more intense in the nontransgenic compared with the K14-HIF-1 $\alpha \Delta$ ODD transgenic mice (arrow indicates a normal sebaceous gland). Bar, $20 \mu \mathrm{m}$. (b) Ear Evans blue dye content 30 min post intravenous injection of K14HIF-1 $1 \alpha \Delta$ ODD transgenic mice and nontransgenic controls. There is an absence of baseline leakage in both transgenic and nontransgenic mice, and a significantly lower leakage in the mustard oil-treated ear. Four to six mice analyzed per group $\left({ }^{\star} P<0.05\right.$, Mann-Whitney $U$ test $) . \quad(c)$ Real-time TaqMan RT-PCR analysis of angiopoietin-1 (Ang-1) expression from total RNA isolated from ears of K14-Ang-1 and K14-HIF-1 $\alpha \Delta$ ODD transgenic mice and nontransgenic controls, using histone $3.3 \mathrm{~A}$ as a reference. Three mice of each genotype were analyzed $\left({ }^{\star} P<0.05, \mathrm{Mann}-\mathrm{Whitney} \mathrm{U}\right.$ test).

leaky at baseline, in the absence of an exogenous stimulus, and somewhat leakage-resistant in response to acute inflammation.

\section{Ricin staining of endothelial leaky sites}

Evans blue dye content is a measurement of vascular permeability across an entire tissue sample but does not examine leakage at individual blood vessels. To begin to elucidate the mechanism of leakage resistance suggested by the Evans blue dye analysis, mice were perfused with biotinylated Ricinus communis I lectin (Fig. 4a). Ricin weakly binds to intact vascular endothelium, but avidly adheres to vascular basement membrane exposed at sites of leakage, and also diffuses out into the perivascular space, staining tissue in the vicinity of blood vessels (Thurston et al. 1999). Ricin therefore allows determination of the number of leaky sites across the vasculature, and also permits a qualitative assessment of the extent of leakage in individual vessels. Ricin perfusion of untreated ears failed to demonstrate leaky sites in either K14-HIF-1 $\alpha \Delta$ ODD or nontransgenic mice (Fig. 4a). These results are consistent with the lack of baseline leakage evident in the untreated K14-HIF-1 $\alpha \Delta$ ODD transgenic mice in the Evans blue dye study (Fig. 4b). In response to mustard oil, both K14-HIF-1 $\alpha \Delta$ ODD and nontransgenic mice displayed numerous leaky sites after treatment (Fig. 4a). Leaky sites were predominantly located in postcapillary venules (Fig. 4a, white arrowheads), compared with capillaries (Fig. 4a, black arrowheads). The intensity of leakage at postcapillary venules was less in the K14-HIF-1 $\alpha \Delta$ ODD transgenic mice compared with the nontransgenic controls treated with mustard oil and likely accounted for the statistically significant decrease in Evans blue content. As such, the permeability response of the microvasculature in the K14-HIF-1 $\alpha \Delta$ ODD transgenic mice is complex. Despite marked induction of VEGF (Fig. 2), the extensive microvasculature induced by HIF-1 $\alpha$ overexpression is leakage-resistant at baseline. However, the microvasculature retains its permeability response during inflammation with a modest decrease in postcapillary venular leakage. These results also support the notion that blood vessels induced by HIF- $1 \alpha$ retain the properties of nontransgenic vasculature in contrast to the microvasculature induced when VEGF164 or VEGF120 is overexpressed in basal keratinocytes (Larcher et al. 1998; Thurston et al. 1999). 


\section{Analysis of angiopoietin-1 and angiopoietin-2 expression}

The property of leakage-resistance resembles the baseline microvascular phenotype of transgenic mice overexpressing angiopoietin-1 (Ang-1; Thurston et al. 1999). As leakage-resistance induced by Ang-1 is dominant over VEGF-mediated increase in permeability (Thurston et al. 1999|, angiopoietins could be responsible for the lack of baseline leakage of the microvasculature induced by HIF- $1 \alpha$ overexpression. To determine whether Ang-1 or Ang-2 expression, also up-regulated by hypoxia (Oh et al. 1999|, was coordinately increased by HIF-1 $\alpha$ overexpression, we performed real-time RT-PCR using PCR primers and TaqMan probes specific for Ang-1 and Ang-2. Ang-1 was expressed at the same low level in ears from both K14-HIF-1 $\alpha \Delta$ ODD transgenic mice and nontransgenic controls (Fig. 4c), compared with a 20-fold elevation of expression detected in ears of K14-Ang-1 transgenic mice (Fig. 4c). Similarly, Ang-2 was expressed at low levels in K14-HIF-1 $\alpha \Delta$ ODD transgenic mice and nontransgenic controls (data not shown). In contrast, Ang-2 was expressed at 45-fold greater level in total RNA from positive control tissue, which was placenta of embryonic day 14 (E14) nontransgenic mouse embryos (data not shown).

Parallel mRNA in situ hybridization analysis of Ang-1 and Ang-2 expression was performed in ear skin obtained from K14-HIF- $1 \alpha$ and K14-HIF- $1 \alpha \Delta$ ODD transgenic mice and compared with Ang-1/Ang-2 expression in E11-E13 embryos (data not shown). There was no detectable hybridization signal for either Ang-1 or Ang-2 in transgenic or nontransgenic ear skin, compared with a strong signal in embryonic atria, aorta, and somites. Therefore, induction of Ang-1 and Ang-2 expression in adult tissue does not play a role in HIF- $1 \alpha$-mediated hypervascularity or lack of baseline microvessel leakage.

\section{Determination of total VEGF $m R N A$ and protein expression}

One possible explanation for the absence of baseline vascular leakage in K14-HIF- $\alpha \Delta$ ODD transgenic mice compared with overt leakage in transgenic mice overexpressing VEGF164 or 121 (Larcher et al. 1998; Thurston et al. 1999) was that constitutive HIF- $\alpha$ overexpression induced lower levels of VEGF expression compared with direct transgenic expression of VEGF cDNA from a keratin-14 promoter. To test this possibility, we performed real-time RT-PCR using PCR primers amplifying exons 3 and 4 of the mouse VEGF-A gene, which are common to all VEGF-A isoforms (Tober et al. 1998), along with a TaqMan probe specific for the exon 3/4 splice junction. Quantitative RT-PCR was performed on total RNA isolated from heterozygous K14-VEGF164, K14-HIF$1 \alpha \Delta$ ODD, and K14-HIF- $1 \alpha$ transgenic mice, along with nontransgenic littermate controls. In contrast to in situ hybridization, the increased sensitivity of real-time RTPCR detected a signal for VEGF mRNA in nontransgenic ear. Total VEGF mRNA levels were elevated $80 \%$ in
K14-HIF-1 $\alpha$ transgenic mice (Fig. 5a), and 8- to 13-fold in the K14-HIF-1 $\alpha \Delta$ ODD transgenic mouse lines compared with nontransgenic controls (Fig. 5a). The levels of VEGF mRNA in ear skin of K14-HIF-1 $\alpha \Delta$ ODD transgenic mice is similar to the 13- to 25-fold elevation of VEGF expression produced by hypoxia in cultured cells (Ikeda et al. 1995; Levy et al. 1995, 1996b; Stein et al. 1998). HIF$1 \alpha \Delta$ ODD-mediated VEGF mRNA induction is within range, although higher, than the 2.5- to 8-fold increase in VEGF mRNA levels in hypoxic tissues (Banai et al. 1994; Lee et al. 1999; Miraliakbari et al. 2000). These differences may be due to sensitivity of the real-time RTPCR used here, compared with the Northern analysis used in prior work. Parallel analysis of total VEGF expression in skin squamous cancers in transgenic mice expressing HPV16 oncogenes revealed a 20- to 30-fold increase in VEGF mRNA (data not shown), indicating that VEGF expression in the K14-HIF-1 $\alpha \Delta$ ODD transgenic mice was not supraphysiologic. Surprisingly, total VEGF mRNA levels were only elevated twofold in K14VEGF164 transgenic mice that were heterozygous for the transgene (Fig. 5a). Increased microvascular leakage and hypervascularity had been previously demonstrated in homozygous K14-VEGF164 transgenic mice (Thurston et al. 1999). However, a projected fourfold elevation of VEGF mRNA expression extrapolated from our data from the heterozygous K14-VEGF164 transgenic mice would still fail to approximate the marked induction of total VEGF mRNA in the K14-HIF- $1 \alpha \Delta$ ODD transgenic mice.

Another outstanding question was whether the marked induction of VEGF mRNA owing to gain of HIF$1 \alpha$ function was also present at the level of protein. Ear protein extracts from HIF- $1 \alpha$, HIF- $1 \alpha \Delta$ ODD, and VEGF164 transgenic mice and nontransgenic controls were analyzed by ELISA (FIG. 5d). K14-HIF-1 $\alpha \Delta$ ODD transgenic mice showed a threefold induction of VEGF protein expression in the two of the three lines (\#19 and \#71) compared with either K14-HIF-1 $\alpha$ or nontransgenic mice (Fig. 5d). Heterozygous K14-VEGF164 transgenic mice displayed a twofold induction of VEGF protein compared with controls (Fig. 5d). These protein levels are likely to underestimate local VEGF concentrations adjacent to transgenic keratinocytes because the whole ear, including dermis, muscle, and cartilage, was homogenized. This level of VEGF protein induction is similar to that reported from ischemic hearts or brains (Banai et al. 1994; Lee et al. 1999, 2000b; Miraliakbari et al. 2000). As such, inadequate induction of VEGF mRNA or VEGF protein cannot explain the lack of baseline leakage mediated by HIF-1 $\alpha \Delta$ ODD overexpression.

\section{Patterns of VEGF isoform expression}

Five isoforms are expressed from the VEGF- $A$ gene (Tober et al. 1998), and it is becoming increasingly apparent that different VEGF isoforms mediate distinct facets of vascular biology (Cheng et al. 1997; Carmeliet et al. 1999; Grunstein et al. 2000). As such, an alternative explanation for disparity in vascular leakage was that the 

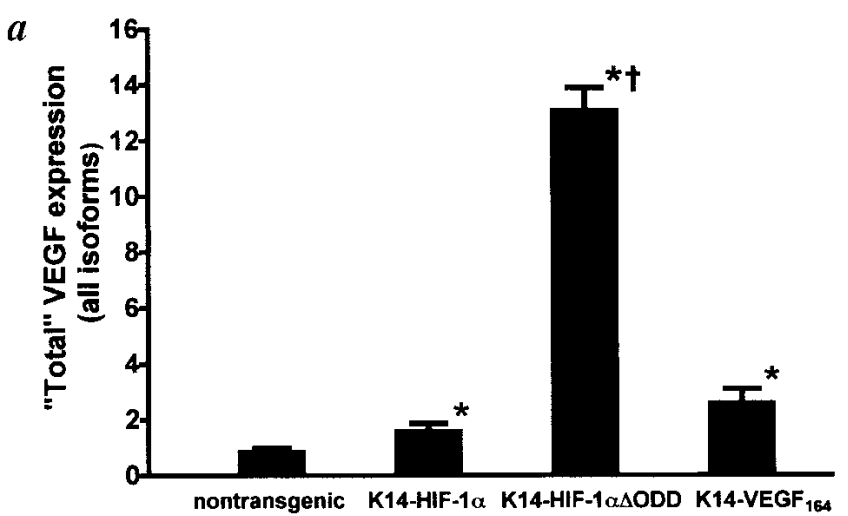

$b$

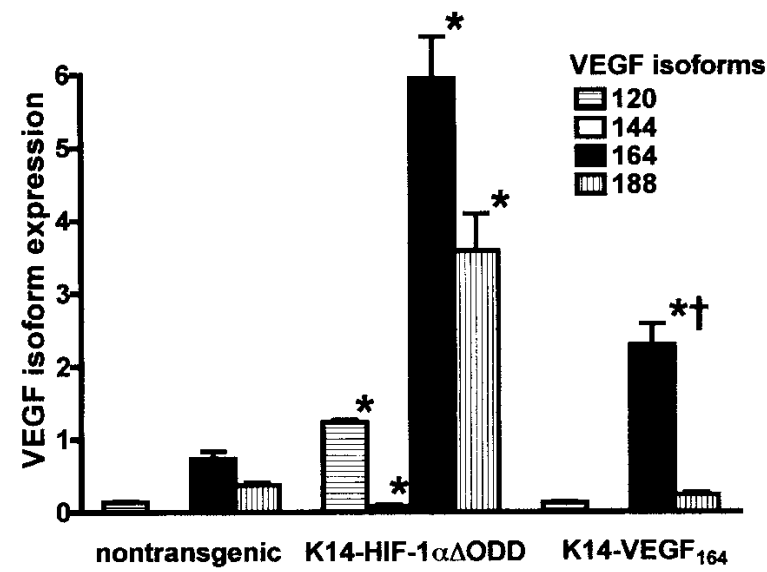

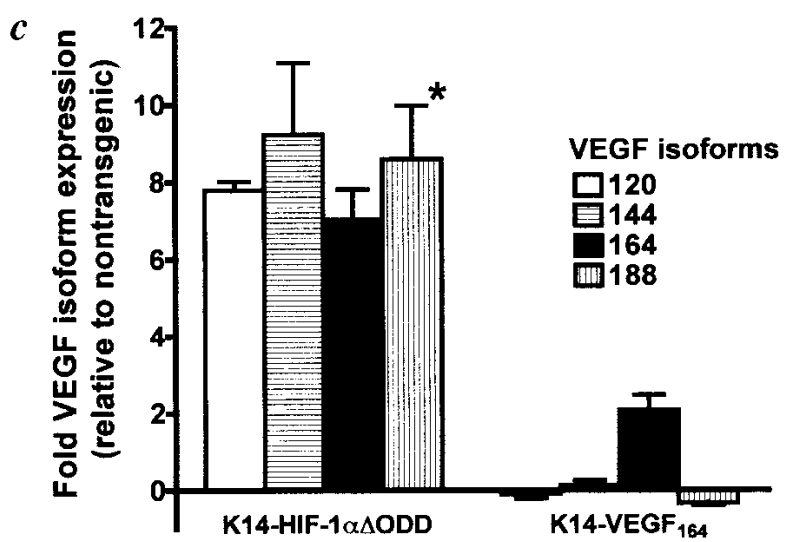

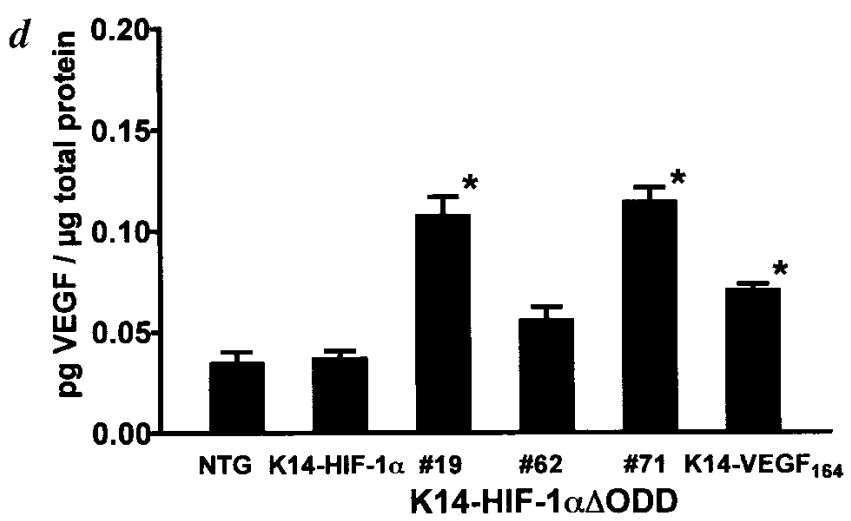

Figure 5. Expression of total VEGF and VEGF isoforms. (a) Real-time RT-PCR determination of total VEGF isoform expression in ear skin of K14-HIF-1 $\alpha$, K14-HIF-1 $\alpha \Delta$ ODD, and K14-VEGF164 transgenic mice and nontransgenic controls. Three mice from each genotype were analyzed, and VEGF mRNA levels are calculated relative to histone 3.3A in each sample. Total VEGF mRNA levels are increased $80 \%$ in K14-HIF- $1 \alpha$ transgenic mice compared with nontransgenic controls $\left({ }^{\star} P=0.02\right.$, Student's $t$-test). Total VEGF mRNA is elevated 13-fold in K14-HIF-1 $\alpha \Delta$ ODD transgenic mice compared with nontransgenic controls $\left({ }^{\star} P<0.0001\right.$, Student's $t$-test), and fourfold compared with K14-VEGF164 transgenic mice $(t P=0.0003$, Student's $t$-test). Total VEGF is elevated twofold in ear skin from K14-VEGF164 transgenic mice compared with nontransgenic controls ( ${ }^{\star} P=0.02$, Student's $t$-test). (b) Real-time RT-PCR determination of VEGF isoform expression in ear skin of nontransgenic controls and K14-HIF-1 $\alpha \Delta$ ODD and K14-VEGF164 transgenic mice. PCR primers flanking each indicated isoform and fluorescent TaqMan probes specific for each splice junction were used in the analysis (Tober et al. 1998). VEGF isoforms in each sample were calculated with histone 3.3A as a reference. Triplicate determinations were performed and the mean was used in calculations. Three to four mice were analyzed in each group $\left({ }^{\star} P<0.05\right.$, compared with level of nontransgenic controls, Mann-Whitney $U$ test; $+P<0.05$ pattern of expression different from nontransgenic, ANOVA with maximum likelihood test). (c) Calculation of the fold induction of each VEGF isoform in K14-HIF-1 $\alpha \Delta$ ODD and K14-VEGF164 transgenic mice compared with nontransgenic controls. There is an equivalent 6- to 10-fold induction of each VEGF isoform in the K14-HIF1 $\alpha \Delta$ ODD transgenic mice, whereas only the 164 isoform is increased in K14-VEGF164 transgenic mice. The pattern of VEGF isoform induction is significantly different in the two groups of transgenic mice $\left({ }^{\star} P<0.05\right.$, ANOVA with maximum likelihood test). (d) VEGF protein levels in transgenic and nontransgenic mice. ELISA analysis of protein extracts from ear skin shows a 0.5- to 3-fold increase of VEGF protein in the three separate K14-HIF-1a $\Delta$ ODD transgenic mouse lines (\#62, \#19, and \#71 in order of magnitude), and a twofold increase in heterozygous K14-VEGF164 transgenic mice, compared with nontransgenic controls and K14-HIF-1 $\alpha$ transgenic mice $\left({ }^{\star} P<0.05\right.$, Student's $t$-test $)$.

composition of VEGF isoform expression was different in the K14-HIF-1 $1 \alpha \Delta$ ODD and the K14-VEGF164 groups. To answer this question, we determined the expression profile of the four most abundant VEGF isoforms (Tober et al. 1998) in ear skin from K14-HIF- $1 \alpha \Delta$ ODD and heterozygous K14VEGF164 transgenic mice and nontransgenic controls. We used real-time RT-PCR with isoformspecific flanking primers and TaqMan probes complementary to the unique splice junctions of VEGF120, VEGF144, VEGF164, and VEGF188 (Fig. 5b). In nontrans- genic mice, VEGF164 was expressed at the highest level (Fig. 5b). VEGF188 was expressed at 50\%, VEGF120 at $19 \%$, and VEGF144 at 1.0\% of the level of VEGF164. The expression level of each VEGF isoform was significantly elevated in the K14-HIF-1 $\alpha \Delta$ ODD transgenic mice compared with nontransgenic controls (Fig. 5b). However, the pattern of isoform expression in K14-HIF-1 $\alpha \Delta$ ODD transgenic mice was not statistically different from that in nontransgenic controls (Fig. 5b). Calculation of the fold-induction of VEGF expression relative to nontrans- 
genic controls revealed an equivalent seven- to ninefold elevation of each of the VEGF isoforms from ear skin of K14-HIF-1 $\alpha \Delta$ ODD transgenic mice (Fig. 5c). In contrast, VEGF164 was the only isoform whose expression was significantly increased compared with nontransgenic controls in the K14-VEGF164 transgenic mice (Fig. 5b,c). Moreover, the twofold elevation of the VEGF164 isoform here, compared with a similar fold-induction in the previous analysis of total VEGF expression (Fig. 5a), both internally validates our real-time RT-PCR techniques and also underscores the sole elevation of the 164 isoform in this transgenic model. Although other possibilities certainly exist, it is conceivable that a balanced induction of each VEGF isoform may be in part responsible for development of a nonleaky microvasculature in response to HIF-1 $\alpha$ overexpression.

\section{Discussion}

Here we show that gain of HIF- $1 \alpha$ function in epidermal keratinocytes induces hypervascularity, leakage resistance, and up-regulation of both VEGF mRNA and protein. The mechanism of this leakage resistance is not associated with a coordinate increase of angiopoietin-1, a known inhibitor of microvessel permeability alone (Suri et al. 1998) or in combination with VEGF (Thurston et al. 1999). As such, gain of HIF-1 $\alpha$ function appears to separate the hypervascular from the permeability function of VEGF. In contrast, prior studies in both transgenic mice and engineered expression systems in intact animals are consistent with a convergence of the vascularity, permeability, and inflammatory functions of VEGF (Detmar et al. 1998; Larcher et al. 1998; Springer et al. 1998; Lee et al. 2000a).

The discrepancy between our study and prior work could reside in the induction of the endogenous VEGF gene with its collection of differentially spliced isoforms, compared with the engineered expression of single candidate VEGF isoforms used in prior work. Previous studies have shown distinctive functions for different VEGF isoforms. Knock-in of VEGF120 only partially rescued lack of VEGF188 and VEGF164 function and extended the life span of knock-in mice compared with conventional targeting of the VEGF gene (Carmeliet et al. 1999). Knock-in rescue experiments in xenotransplanted rastransformed embryonic stem cells showed distinctive differences in microvascular morphology, density, and perfusion produced by VEGF188, VEGF164, or VEGF120 (Grunstein et al. 2000). Earlier orthotopic implantation studies of transfected cell lines also showed that different VEGF isoforms appeared to mediate different effects on vascular permeability and tumor vascular density (Cheng et al. 1997). Differential heparin-binding affinities and creation of concentration gradients and focal accumulations of VEGF isoforms across the tissue could underlie some aspects of isoform-specific vascular biology (Ng et al. 2001). These concentration gradients could distinctly engage proliferative, survival or maintenance, and permeability functions by differential activation of intracellular signaling pathways. Alternatively, or in addition, isoform specificity for different cell surface receptors has been shown. In particular, VEGF164 and VEGF 120 have been shown to bind differentially to the neuropilin-1 (NP-1) or NP-2 receptors (Soker et al. 1998; Gluzman-Poltorak et al. 2000). Although the role of these receptors in de novo VEGF signaling is obscure, each has been shown to heterodimerize with VEGFR-1 and VEGFR-2. In this context, they may modulate intracellular signaling from these classical VEGF receptors. Finally, there is the possibility that gain of HIF-1 $\alpha$ function may increase expression of novel targets that may modulate vascular permeability, independent of VEGF function.

As induction of HIF- $1 \alpha$ expression and function appears to be an essential component of the hypoxic cellular response, a conclusion derived from our study could be that tissue hypoxia, in particular epithelial hypoxia, mediates induction of a leakage-resistant vasculature. However, additional cell types, such as endothelial cells, pericytes, and macrophages, coexist in epithelia. Induction of HIF- $1 \alpha$ in these stromal cells could, and likely does, affect vascular biology. Moreover, the HIF-1 $\alpha$ target gene repertoire may be cell-type specific and distinctive in endothelial versus epithelial cells. For instance, both $f 1 t-1$ and iNOS are known HIF-1 $\alpha$ target genes in endothelial cells, yet our preliminary data (not shown) suggest that these genes are not up-regulated in the K14HIF- $1 \alpha \Delta$ ODD transgenic mice. Moreover, hypoxia itself may induce additional cytokine expression or recruit other master regulatory transcription factors within specific cell types, such as Egr-1 up-regulation in hypoxic endothelium (Jin et al. 2000), that may mediate blood vessel permeability alone or combined with HIF-1 $\alpha$ stabilization. Additional modulators of permeability may also exist in vessels in hypoxic wounds and tumors, which are known to be leaky (for review, see Carmeliet and Jain 2000). Fragility and leakiness of tumor vasculature in particular (Hashizume et al. 2000) may be caused by combinations of molecular and physical alterations including paracrine signaling from oncogene up-regulation within the malignant cells (Pelengaris et al. 1999), formation of mosaic vessels partially lined by tumor cells intercalated between endothelial cells (Chang et al. 2000), and up-regulation of placental growth factor in combination with VEGF (Carmeliet et al. 2001).

Our study also shows that gain of HIF-1 $\alpha$ function alone can affect both induction of VEGF mRNA expression and a downstream angiogenic phenotype in the absence of actual tissue hypoxia. Nuclear run-on studies have suggested that transcriptional regulation accounts for, at most, a two- to threefold induction of VEGF mRNA levels (Levy et al. 1995). As VEGF mRNA levels are increased by 12- to 25-fold in cultured cells exposed to hypoxia, the majority of this VEGF mRNA induction likely resides in increased mRNA stability (Levy et al. 1996b; Stein et al. 1998). Multiple regulatory elements exist in the in $5^{\prime}$ and $3^{\prime}$ untranslated regions (UTRs) of VEGF mRNA that are controlled by the ambient oxygen 
concentration (Levy et al. 1996b; Stein et al. 1998). Hypoxia has been concomitantly shown to induce sequencespecific 3'-UTR-binding proteins that may mediate VEGF stability (Levy et al. 1996a, 1997). At the level of protein, an internal ribosome entry site is present within the 5' UTR that facilitates translation and VEGF protein expression in hypoxia (Stein et al. 1998). Therefore, our data suggest several possibilities for the induction of hypervascularity in the K14-HIF- $1 \alpha \Delta \mathrm{ODD}$ transgenic mice. One possibility is that these regulatory elements in VEGF mRNA are inconsequential in the context of VEGF expression in intact epithelial tissue, and here the majority of increase in VEGF mRNA is created by transcriptional activity. Alternatively, induction of HIF-1 $\alpha$ function itself may regulate both transcriptional and posttranscriptional elements of VEGF expression. As such, there is the possibility that HIF-1 itself may increase expression of $3^{\prime}$-UTR-binding proteins that increase VEGF mRNA stability in hypoxia. This speculation is indirectly supported by the demonstration that the von Hippel-Lindau gene product, which targets HIF- $1 \alpha$ itself for ubiquitination /Cockman et al. 2000; Ohh et al. 2000; Ivan et al. 2001; Jaakkola et al. 2001), regulates VEGF mRNA expression by upregulating these $3^{\prime}$-UTR-binding proteins (Levy et al. 1996a).

Our work also suggests that HIF-1 $\alpha$ overexpression might be efficacious as gene therapy for tissue ischemia. Induction of vascular malformations and vascular tumors in response to chronic VEGF164 exposure following gene transfer (Lee et al. 2000a), or acceleration of atherosclerosis during chronic systemic VEGF administration (Celletti et al. 2001), highlights alternative approaches to increase vascularization of ischemic tissues. Gene and pharmacological therapy to induce gain of wild-type HIF-1 $\alpha$ function has been proposed for both cardiac and peripheral vascular disease (Lee et al. 2000a,b; Li et al. 2000; Vincent et al. 2000). In response to profound hypoxia, expression of endogenous HIF- $1 \alpha$ actually decreases; therefore the HIF-1 $\alpha \Delta$ ODD mutant might be more efficacious than wild-type HIF- $1 \alpha$ in extremely ischemic cells (Jiang et al. 1996). Use of the HIF$1 \alpha \Delta$ ODD mutant also preserves the original potent transactivation domain, which may be advantageous in terms of levels and spectrum of target gene expression compared with a constitutively active mutant with a heterologous transactivation domain /Vincent et al. 2000). Gain of HIF-1 $\alpha$ function may be particularly applicable for diabetic peripheral vascular disease, which is frequently complicated by chronic leg ulcers that can precipitate amputation. Diabetes produces a marked decrease in VEGF expression from either ischemic muscle (Rivard et al. 1999) or skin wounds (Frank et al. 1995). The combination of HIF-1-induced up-regulation of VEGF with attendant development of a stable, nonleaky microvasculature and increased expression of glucose transporters and glycolytic enzymes might hold the promise of enhanced cellular metabolism and increased perfusion within ischemic diabetic limbs with recalcitrant wounds.

\section{Materials and methods}

Transgene construction

Plasmids $\quad \mathrm{p}(\mathrm{HA}) \mathrm{HIF}-1 \alpha$ and $\mathrm{p}(\mathrm{HA}) \mathrm{HIF}-1 \alpha(401 \Delta 603)$ (HIF$1 \alpha \Delta$ ODD; Huang et al. 1998) were digested with XbaI and Asp718I to release cDNA inserts, gel-purified over QIAquick columns (QIAGEN), blunted with Klenow polymerase, and blunt-end-cloned into an SmaI-linearized K14 expression cassette (Munz et al. 1999). Plasmid DNA was prepared with QIAGEN Endofree Plasmid Maxi Kit. Entire transgene inserts were liberated from vector by Asp718I digestion, purified, and electroeluted from acrylamide gels (Arbeit et al. 1994).

\section{Histopathology and RNA in situ hybridization}

Sections of paraformaldehyde-fixed, paraffin-embedded ear tissue $5 \mu \mathrm{m}$ thick were cut and stained with hematoxylin and eosin (Sigma) for histopathological analysis, and mRNA in situ hybridization was performed using ${ }^{35} \mathrm{~S}$-radiolabeled cRNA riboprobes as described previously (Arbeit et al. 1996). A riboprobe complementary to human HIF- $1 \alpha$ cDNA was used for transgene expression, whereas riboprobes complementary to mouse VEGF and GLUT-1 were used for HIF-1 target gene expression (Arbeit et al. 1996).

\section{CD31 immunohistochemistry}

Frozen tissue sections $10 \mu \mathrm{m}$ thick were mounted on Superfrost Plus slides (Fisher Scientific), air dried, fixed in acetone at $4^{\circ} \mathrm{C}$ for $10 \mathrm{~min}$., air dried again, and washed in $1 \times$ PBS. Sections were blocked in a combined solution of $5 \%$ normal goat serum (Cappel-Organon Teknika)/3\% bovine serum albumin (Sigma)/2\% fish gelatin (Sigma) in PBS at $25^{\circ} \mathrm{C}$ for $30 \mathrm{~min}$, preincubated with Avidin solution for $15 \mathrm{~min}$, followed by biotin for $15 \mathrm{~min}$ (Avidin-Biotin Blocking Kit; Vector Laboratories). Sections were then incubated with biotinylated rat anti-mouse CD31 monoclonal antibody (Pharmingen), diluted 1:2500 in blocking buffer at $4^{\circ} \mathrm{C}$ overnight, followed by serial incubation with a biotinylated goat anti-rat IgG (Pierce), ABC Alkaline Phosphatase Standard solution (Vector), and BCIP/NBT Alkaline Phosphatase Substrate Kit IV (Vector). Sections were counterstained with nuclear fast red (Vector). Vessel density per unit area was quantified from three random $40 \times$ fields using a Chalkley reticule. Statistical significance was determined using the Mann-Whitney U test (GraphPad Prism).

\section{Whole mount vessel staining}

Transgenic and nontransgenic mice $8-12$ weeks of age were anesthetized and injected intravenously via the femoral vein with biotinylated Lycopersicon esculentum lectin (Vector), 100 $\mu \mathrm{g} /$ mouse, followed by perfusion through the aorta with $1 \%$ paraformaldehyde plus $0.5 \%$ glutaraldehyde $(\mathrm{pH} 7.4)$. The ears were removed, and the skin was separated from cartilage and stained with $\mathrm{ABC}$ (peroxidase) and 3,3'-diaminobenzidine. Vessel length-density was determined using a computerized algorithm (Thurston et al. 1999). For fluorescent visualization, mice were injected with fluoresceinated lectin (Vector), $120 \mathrm{\mu g} /$ mouse, followed by perfusion with $1 \%$ paraformaldehyde $(\mathrm{pH}$ 7.4). The ears were dissected and embedded in tissue-freezing medium, cut in $40-\mu \mathrm{m}$ sections, mounted, and visualized by epifluorescence.

\section{Vascular leakage}

Transgenic and nontransgenic mice $8-12$ wk of age were anesthetized (ketamine/xylazine) and injected intravenously with 
Evans blue dye, $30 \mathrm{mg} / \mathrm{kg}$ per mouse. The right ear was treated twice over 30 min with mustard oil $15 \%$ in heavy mineral oil; Sigma). Mice were perfused through the aorta with $1 \%$ paraformaldehyde in citrate buffer at $\mathrm{pH}$ 3.5. The ears were dissected and weighed. Extravasated dye was extracted with formamide and quantified with a spectrophotometer $(610 \mathrm{~nm})$. Ricin staining was performed using a similar protocol on mice of similar age. Under anesthesia, 5\% mustard oil was applied topically to one ear. The mice were perfused with fixative ( $1 \%$ paraformaldehyde plus $0.5 \%$ glutaraldehyde) 20 min later, and the vasculature was stained by perfusion of biotinylated ricin lectin, 200 $\mu \mathrm{g} /$ mouse (Ricinus communis I, Vector). The ears were removed, the skin was dissected from the cartilage as a whole mount, and the lectin was visualized by reaction with avidin peroxidase and diaminobenzidine substrate.

\section{Quantitative RT-PCR}

Ear tissue was dissected from mice, snap-frozen, and homogenized in TRIzol (Life Technologies). Total RNA was extracted according to the manufacturer's instructions and treated with 2 U/sample RQ1 DNase (Promega). cDNAs were made from 500ng RNA samples, in $100-\mu \mathrm{L}$ reactions using M-MLV reverse transcriptase and random hexamers incubated at $25^{\circ} \mathrm{C}$ for 10 min then $48^{\circ} \mathrm{C}$ for $30 \mathrm{~min}$. Expression of total VEGF, angiopoietin-1, and angiopoietin-2 was analyzed using the $5^{\prime}$ nuclease assay (real-time TaqMan RT-PCR; Livak et al. 1995) with the ABI PRISM 7700 instrument (ABI). PCR was conducted in triplicate with $50-\mu \mathrm{L}$ reaction volumes of $1 \times$ PCR buffer $\mathrm{A}(\mathrm{ABI}), 5.5$ $\mathrm{mM} \mathrm{MgCl}{ }_{2}, 0.9 \mu \mathrm{M}$ each primer, $200 \mu \mathrm{M}$ dNTPs, $200 \mathrm{nM}$ probe, and $0.025 \mathrm{U} / \mu \mathrm{L}$ Taq Gold (ABI). Sequences of the PCR primers and TaqMan probes were: mouse total VEGF forward (exon 3), 5'-CTGTGCAGGCTGCTGTAACG-3'; reverse (exon 4), 5' GCTCATTCTCTCTATGTGCTGGC-3'; TaqMan probe, 5'FAM(6-carboxy-fluorescein)-CACCATGCAGATCATGCGGAT CAAAC-TAMRA(6-carboxy-tetramethyl-rhodamine)-3' (Integrated DNA Technologies); mouse Ang-1 forward, 5'GCAAATGCGCTCTCATGCTA-3'; reverse, 5'-GGAGTAAC TGGGCCCTTTGAA-3'; TaqMan probe, 5'-FAM-AGGTTG GTGGTTCGATGCCTGTGG-TAMRA-3' (Integrated DNA Technologies); and mouse Ang-2 forward, 5'-TGACAGCCAC GGTCAA CAAC-3'; reverse, 5'-ACGGATAGCAACCGAGCT CTT-3'; TaqMan probe, 5'-FAM-CAGCAGCATGACCTAATG GAGACCGTC-TAMRA-3' (Integrated DNA Technologies). PCR cycling conditions were the same for all three cDNAs, consisting of $95^{\circ} \mathrm{C}$ for $15 \mathrm{~min}$ and 40 cycles of $95^{\circ} \mathrm{C}$ for $30 \mathrm{sec}$, $60^{\circ} \mathrm{C}$ for $1 \mathrm{~min}$. Relative expression levels were calculated as detailed previously (Ginzinger et al. 2000). Briefly, relative ex-

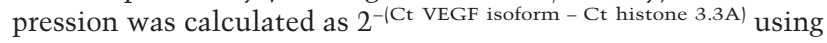
histone $3.3 \mathrm{~A}$ as an endogenous control gene.

\section{VEGF isoform expression}

PCR primers specific for splice variants and TaqMan probes spanning each isoform's unique splice junction were generated. The sequences of mouse VEGF isoform-specific PCR primers were: VEGF188 (F), 5'-CGAAAGCGCAAGAAATCCC-3'; (R), 5'-TGCTTTCTCCGCTCTGAACA-3'; VEGF164 (F), 5'-CATA GAGAGAATGAGCTTCCTACAGC-3'; (R), 5'-TGCTTTCT CCGCTCTGAACA-3'; VEGF144 (F), 5'-AGCCAGAAAAAAA ATCAGTTCGAG-3'; (R), 5'-CCTGAGGGAGGCTCCTTCC-3'; VEGF120 (F), 5'-AGCAGATGTGAATGCAGACCAA-3'; (R), 5'-CTCCTTCCTGCCAGCCTG-3'. Dual-label TaqMan probe sequences were: VEGF 188, 5'-FAM-TAAATCCTGGAGCGTT CACTGTGAGCC-BHQ-3' (Black hole quencher; Biosearch Technologies); VEGF164, 5'-FAM-AGAACAAAGCCAGAAAATCAC
TGTGAGCCTT-BHQ-3'; VEGF144, 5'-FAM-AAATCCTGGAG CGTATGTGACAAGCCAAG-BHQ-3'; VEGF120, 5' -FAM-ACA AAGCCAGAAAAATGTGACAAGCCAA-BHQ-3'. PCR conditions were identical to those described for Ang-1 and Ang-2. Histone $3.3 \mathrm{~A}$ was used as a reference.

\section{VEGF ELISA}

From each mouse one-fourth of one ear was clipped and snapfrozen, then homogenized on ice at high speed for $1 \mathrm{~min}$ in 200-300 $\mu \mathrm{L}$ of RIPA buffer (150 mM NaCl, 1\% NP-40, 0.5\% DOC, $0.1 \%$ SDS, $50 \mathrm{mM}$ Tris at $\mathrm{pH} 8.0$ ) containing $1 \times$ Complete Mini Protease Inhibitors (Roche) and 0.5 mM EDTA. Extracts were incubated on ice for at least $30 \mathrm{~min}$ with occasional vortexing and centrifuged at $14,000 \mathrm{rpm}$ for $10 \mathrm{~min}$. Supernatants were reserved and protein concentrations were determined with the DC Protein Assay (Bio-Rad). The VEGF content of $10 \mu \mathrm{g}$ of total protein was determined using the Quantikine $M$ kit (R \& D Systems) according to the manufacturer's instructions. Plates were read and analyzed on a SPECTRAmax 340 running SOFTmax PRO 3.1.1 (Molecular Devices).

\section{Acknowledgments}

The authors thank Nicole Glazer and Mamie Yu for their excellent technical support and Gerard Evan, Joe Gray, Frank McCormick, and Katie Nason for comments on the manuscript. The authors thank Jocelyn Holash (Regeneron Pharmaceuticals) for gifts of tissue from K14-VEGF164 and K14-Ang-1 transgenic mice, and Mallika Singh for obtaining these samples. The authors also thank Sabina Werner (Martinsreid, Germany), for her gift of the human keratin-14 expression cassette. This work was supported by CA-71398 to J.M.A. and HL-24136 and HL-59157 to D.M.

The publication costs of this article were defrayed in part by payment of page charges. This article must therefore be hereby marked "advertisement" in accordance with 18 USC section 1734 solely to indicate this fact.

\section{References}

Arbeit, J. 1996. Transgenic models of epidermal neoplasia and multi-stage carcinogenesis. Cancer Surv. 26: 7-34.

Arbeit, J., Münger, K., Howley, P., and Hanahan, D. 1994. Progressive squamous epithelial neoplasia in K14-human papillomavirus type 16 transgenic mice. I. Virology 68: 4358-4368.

Arbeit, J., Olson, D., and Hanahan, D. 1996. Upregulation of fibroblast growth factors and their receptors during multistage epidermal carcinogenesis in K14-HPV16 transgenic mice. Oncogene 13: 1847-1857.

Banai, S., Shweiki, D., Pinson, A., Chandra, M., Lazarovici, G., and Keshet, E. 1994. Upregulation of vascular endothelial growth factor expression induced by myocardial ischaemia: Implications for coronary angiogenesis. Cardiovasc. Res. 28: 1176-1179.

Carmeliet, P. and Jain, R. 2000. Angiogenesis in cancer and other diseases. Nat. Cell Biol. 407: 249-257.

Carmeliet, P., Ng, Y., Nuyens, D., Theilmeier, G., Brusselmans, K., Cornelissen, I., Ehler, E., Kakkar, V., Stalmans, I., Mattot, V., et al. 1999. Impaired myocardial angiogenesis and ischemic cardiomyopathy in mice lacking the vascular endothelial growth factor isoforms VEGF164 and VEGF188. Nat. Med. 5: 495-502.

Carmeliet, P., Moons, L., Luttun, A., Vincenti, V., Compernolle, 
V., De Mol, M., Wu, Y., Bon, F., Devy, L., Beck, H., et al. 2001. Synergism between vascular endothelial growth factor and placental growth factor contributes to angiogenesis and plasma extravasation in pathological conditions. Nat. Med. 7: 575-583.

Celletti, F., Waugh, J., Amabile, P., Brendolan, A., Hilfiker, P., and Dake, M. 2001. Vascular endothelial growth factor enhances atherosclerotic plaque progression. Nat. Med. 7: 425429.

Chalkley, H. 1943. Method for the quantitative morphologic analysis of tissues. J. Natl. Cancer Inst. 4: 47-53.

Chang, Y., diTomaso, E., McDonald, D., Jones, R., Jain, R., and Munn, L. 2000. Mosaic blood vessels in tumors: Frequency of cancer cells in contact with flowing blood. Proc. Natl. Acad. Sci. 97: 14608-14613.

Cheng, S., Nagane, M., Huang, H., and Cavenee, W. 1997. Intracerebral tumor-associated hemorrhage caused by overexpression of the vascular endothelial growth factor isoforms VEGF121 and VEGF165 but not VEGF189. Proc. Nat1. Acad. Sci. 94: 12081-12087.

Cockman, M.E., Masson, N., Mole, D.R., Jaakkola, P., Chang, G.W., Clifford, S.C., Maher, E.R., Pugh, C.W., Ratcliffe, P.J., and Maxwell, P.H. 2000. Hypoxia inducible factor- $\alpha$ binding and ubiquitylation by the von Hippel-Lindau tumor suppressor protein. J. Biol. Chem. 275: 25733-25741.

Detmar, M., Brown, L., Schon, M., Elicker, B., Velasco, P., Richard, L., Fukumura, D., Monsky, W., Claffey, K., and Jain, R. 1998. Increased microvascular density and enhanced leukocyte rolling and adhesion in the skin of VEGF transgenic mice. J. Invest. Derm. 111: 1-6.

Dvorak, H., Nagy, J., Feng, D., Brown, L., and Dvorak, A. 1999. Vascular permeability factor/vascular endothelial growth factor and the significance of microvascular hyperpermeability in angiogenesis. Curr. Topics Microbiol. Immunol. 237: 97-132.

Elson, D., Ryan, H., Snow, J., Johnson, R., and Arbeit, J. 2000. Coordinate up-regulation of hypoxia inducible factor (HIF)$1 \alpha$ and HIF- 1 target genes during multi-stage carcinogenesis and wound healing. Cancer Res. 60: 6189-6195.

Feldser, D., Agani, F., Iyer, N., Pak, B., Ferreira, G., and Semenza, G. 1999. Reciprocal positive regulation of hypoxiainducible factor $1 \alpha$ and insulin-like growth factor 2. Cancer Res. 59: 3915-3918.

Frank, S., Hubner, G., Breier, G., Longaker, M., Greenhalgh, D., and Werner, S. 1995. Regulation of vascular endothelial growth factor expression in cultured keratinocytes. J. Biol. Chem. 270: 12607-12613.

Gat, U., DasGupta, R., Degenstein, L., and Fuchs, E. 1998. De novo hair follicle morphogenesis and hair tumors in mice expressing a truncated $\beta$-catenin in skin. Cell 95: 605-614.

Ginzinger, D., Godfrey, T., Nigro, J., Moore, D., Suzuki, S., Pallavicini, M., Gray, J., and Jensen, R. 2000. Measurement of DNA copy number at microsatellite loci using quantitative PCR analysis. Cancer Res. 60: 5405-5409.

Gluzman-Poltorak, Z., Cohen, T., Herzog, Y., and Neufeld, G. 2000. Neuropilin-2 is a receptor for the vascular endothelial growth factor (VEGF) forms VEGF-145 and VEGF-165. $J$. Biol. Chem. 275: 29922.

Grunstein, J., Masbad, J., Hickey, R., Giordano, F., and Johnson, R. 2000. Isoforms of vascular endothelial growth factor act in a coordinate fashion to recruit and expand tumor vasculature. Mol. Cell. Biol. 20: 7282-7291.

Hashizume, H., Baluk, P., Morikawa, S., McLean, J., Thurston, G., Roberge, S., Jain, R., and McDonald, D. 2000. Openings between defective endothelial cells explain tumor vessel leakiness. Am. J. Pathol. 156: 1363-1380.
Huang, L., Gu, J., Schau, M., and Bunn, H. 1998. Regulation of hypoxia-inducible factor $1 \alpha$ is mediated by an $\mathrm{O}_{2}$-dependent degradation domain via the ubiquitin-proteasome pathway. Proc. Natl. Acad. Sci. 95: 7987-7992.

Ikeda, E., Achen, M.G., Breier, G., and Risau, W. 1995. Hypoxiainduced transcriptional activation and increased mRNA stability of vascular endothelial growth factor in C6 glioma cells. J. Biol. Chem. 270: 19761-19766.

Ivan, M., Kondo, K., Yang, H., Kim, W., Valiando, J., Ohh, M., Salic, A., Asara, J.M., Lane, W.S., and Kaelin, W.G., Jr. 2001. HIF $\alpha$ targeted for VHL-mediated destruction by proline hydroxylation: Implications for $\mathrm{O}_{2}$ sensing. Science 292: 464 468.

Iyer, N., Kotch, L., Agani, F., Leung, S., Laughner, E., Wenger, R., Gassmann, M., Gearhart, J., Lawler, A., Yu, A., et al. 1998. Cellular and developmental control of $\mathrm{O}_{2}$ homeostasis by hypoxia-inducible factor $1 \alpha$. Genes \& Dev. 12: 149-162.

Jaakkola, P., Mole, D.R., Tian, Y.M., Wilson, M.I., Gielbert, J., Gaskell, S.J., Kriegsheim, A., Hebestreit, H.F., Mukherii, M., Schofield, C.J., et al. 2001. Targeting of HIF- $\alpha$ to the von Hippel-Lindau ubiquitylation complex by $\mathrm{O}_{2}$-regulated prolyl hydroxylation. Science 292: 468-472.

Jiang, B., Semenza, G., Bauer, C., and Marti, H. 1996. Hypoxiainducible factor 1 levels vary exponentially over a physiologically relevant range of $\mathrm{O}_{2}$ tension. Am. J. Physiology 271: C1172-C1180.

Jin, N., Hatton, N., Swartz, D.R., Xia, X., Harrington, M.A., Larsen, S.H., and Rhoades, R.A. 2000. Hypoxia activates jun$\mathrm{N}$-terminal kinase, extracellular signal-regulated protein kinase, and p38 kinase in pulmonary arteries. Am. J. Respir. Cell. Mol. Biol. 23: 593-601.

Larcher, F., Murillas, R., Bolontrade, M., Conti, C.J., and Jorcano, J.L. 1998. VEGF/VPF overexpression in skin of transgenic mice induces angiogenesis, vascular hyperpermeability and accelerated tumor development. Oncogene 17: 303 311 .

Lee, M., Ju, W., Cha, J., Son, B., Chun, M., Kang, J., and Park, C. 1999. Expression of vascular endothelial growth factor mRNA following transient forebrain ischemia in rats. Neurosci. Lett. 265: 107-110.

Lee, R., Springer, M., Blanco-Bose, W., Shaw, R., Ursell, P., and Blau, H. 2000a. VEGF gene delivery to myocardium: Deleterious effects of unregulated expression. Circulation 102: 898-901.

Lee, S., Wolf, P., Escudero, R., Deutsch, R., Jamieson, S., and Thistlewaite, P. 2000b. Early expression of angiogenesis factors in acute myocardial ischemia and infarction. New Engl. J. Med. 342: 626-633.

Levy, A.P., Levy, N.S., Wegner, S., and Goldberg, M.A. 1995. Transcriptional regulation of the rat vascular endothelial growth factor gene by hypoxia. J. Biol. Chem. 270: 1333313340.

Levy, A.P., Levy, N.S., and Goldberg, M.A. 1996a. Hypoxia-inducible protein binding to vascular endothelial growth factor mRNA and its modulation by the von Hippel-Lindau protein. J. Biol. Chem. 271: 25492-25497.

. 1996b. Post-transcriptional regulation of vascular endothelial growth factor by hypoxia. J. Biol. Chem. 271: 27462753.

Levy, N.S., Goldberg, M.A., and Levy, A.P. 1997. Sequencing of the human vascular endothelial growth factor (VEGF) 3' untranslated region (UTR): Conservation of five hypoxia-inducible RNA-protein binding sites. Biochim. Biophys. Acta 1352: $167-173$.

Li, J., Post, M., Volk, R., Gao, Y., Li, M., Metais, C., Sato, K., Tsai, J., Aird, W., Rosenberg, R., et al. 2000. PR39, a peptide 
regulator of angiogenesis. Nat. Med. 6: 49-55.

Livak, K., Flood, S., Marmato, J., Giusti, W., and Deetz, K. 1995. Oligonucleotides with fluorescent dyes at opposite ends provide a quenched probe system useful for detecting PCR product and nucleic acid hybridization. PCR Meth. Appl. 4: 357362 .

Miraliakbari, R., Francalancia, N.A., Lust, R.M., Gerardo, J.A., Ng, P.C., Sun, Y.S., and Chitwood, W.R., Jr. 2000. Differences in myocardial and peripheral VEGF and KDR levels after acute ischemia. Ann. Thorac. Surg. 69: 1750-1754.

Munz, B., Smola, H., Engelhardt, F., Bleuel, K., Brauchle, M., Lein, I., Evans, L., Huylebroeck, D., Balling, R., and Werner, S. 1999. Overexpression of activin A in the skin of transgenic mice reveals new activities of activin in epidermal morphogenesis, dermal fibrosis and wound repair. EMBO $I$. 18: 5205-5215.

Ng, Y.S., Rohan, R., Sunday, M.E., Demello, D.E., and D'Amore, P.A. 2001. Differential expression of VEGF isoforms in mouse during development and in the adult. Dev. Dyn. 220: 112-121.

Oh, H., Takagi, H., Suzuma, K., Otani, A., Matsumura, M., and Honda, Y. 1999. Hypoxia and vascular endothelial growth factor selectively up-regulate angiopoietin-2 in bovine microvascular endothelial cells. I. Biol. Chem. 274: 15732-15739.

Ohh, M., Park, C., Ivan, M., Hoffman, M., Kim, T., Huang, L., Pavletich, N., Chau, V., and Kaelin, W. 2000. Ubiquitination of hypoxia-inducible factor requires direct binding to the $\beta$-domain of the von Hippel-Lindau protein. Nat. Cell Biol. 2: $423-427$.

Pelengaris, S., Littlewood, T., Khan, M., Elia, G., and Evan, G. 1999. Reversible activation of c-Myc in skin: Induction of a complex neoplastic phenotype by a single oncogenic lesion. Mol. Cell 3: 565-577.

Rivard, A., Silver, M., Chen, D., Kearney, M., Magner, M., Annex, B., Peters, K., and Isner, J. 1999. Rescue of diabetesrelated impairment of angiogenesis by intramuscular gene therapy with adeno-VEGF. Am. J. Pathology 154: 355-363.

Ryan, H., Lo, J., and Johnson, R. 1998. HIF-1 $\alpha$ is required for solid tumor formation and embryonic vascularization. EMBO J. 17: 3005-3015.

Semenza, G. 1999. Regulation of mammalian $\mathrm{O}_{2}$ homeostasis by hypoxia-inducible factor 1. Ann. Rev. Cell Dev. Biol. 15: $551-78$.

-2000. Hypoxia, clonal selection, and the role of HIF-1 in tumor progression. Crit. Rev. Biochem. Mol. Biol. 35: 71103.

Soker, S., Takashima, S., Miao, H.Q., Neufeld, G., and Klagsbrun, M. 1998. Neuropilin-1 is expressed by endothelial and tumor cells as an isoform-specific receptor for vascular endothelial growth factor. Cell 92: 735-745.

Springer, M., Chen, A., Kraft, P., Bednarski, M., and Blau, H. 1998. VEGF gene delivery to muscle: Potential role for vasculogenesis in adults. Mol. Cell 2: 549-558.

Stein, I., Itin, A., Einat, P., Skaliter, R., Grossman, Z., and Keshet, E. 1998. Translation of vascular endothelial growth factor mRNA by internal ribosome entry: Implications for translation under hypoxia. Mol. Cell. Biol. 18: 3112-3119.

Suri, C., McClain, J., Thurston, G., McDonald, D., Zhou, H., Oldmixon, E., Sato, T., and Yancopoulos, G. 1998. Increased vascularization in mice overexpressing angiopoietin-1. Science 282: 468-471.

Thurston, G., Baluk, P., Hirata, A., and McDonald, D. 1996. Permeability-related changes revealed at endothelial cell borders in inflamed venules by lectin binding. Am. J. Physiology 271: H2547-H2562.
Thurston, G., Suri, C., Smith, K., McClain, J., Sato, T., Yancopoulos, G., and McDonald, D. 1999. Leakage-resistant blood vessels in mice transgenically overexpressing angiopoietin1. Science 286: 2511-2514.

Tober, K., Cannon, R., Spalding, J., Oberyszyn, T., Parrett, M., Rackoff, A., Oberyszyn, A., Tennant, R., and Robertson, F. 1998. Comparative expression of novel vascular endothelial growth factor/vascular permeability factor transcripts in skin, papillomas, and carcinomas of v-Has-ras Tg.AC transgenic mice and FVB/n mice. Biochem. Biophys. Res. Comm. 247: 644-653.

Vincent, K., Shyu, K., Luo, Y., Magner, M., Tio, R., Jiang, C., Goldberg, M., Akita, G., Gregory, R., and Isner, J. 2000. Angiogenesis is induced in a rabbit model of hindlimb ischemia by naked DNA encoding an HIF-1a/VP16 hybrid transcription factor. Circulation 102: 2255-2261.

Wenger, R. 2000. Mammalian oxygen sensing, signaling and gene regulation. J. Exp. Biol. 203: 1253-1263.

Zhong, H., Agani, F., Baccala, A., Laughner, E., Rioseco-Camacho, N., Isaacs, W., Simons, J., and Semenza, G. 1998. Increased expression of hypoxia inducible factor- $1 \alpha$ in rat and human prostate cancer. Cancer Res. 58: 5280-5284. 


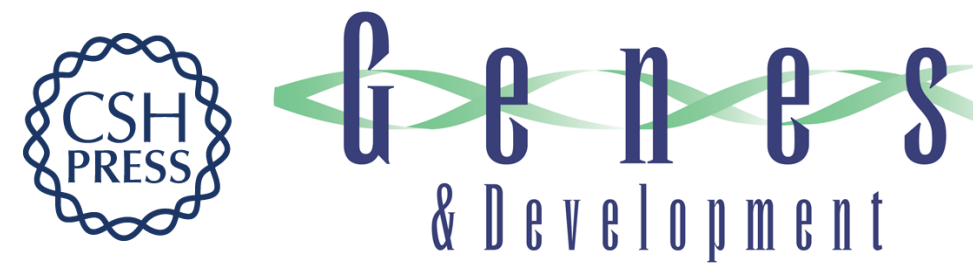

\section{Induction of hypervascularity without leakage or inflammation in transgenic mice overexpressing hypoxia-inducible factor-1 $\alpha$}

David A. Elson, Gavin Thurston, L. Eric Huang, et al.

Genes Dev. 2001, 15:

Access the most recent version at doi:10.1101/gad.914801

References This article cites 57 articles, 28 of which can be accessed free at: http://genesdev.cshlp.org/content/15/19/2520.full.html\#ref-list-1

License

Email Alerting Receive free email alerts when new articles cite this article - sign up in the box at the top Service right corner of the article or click here.

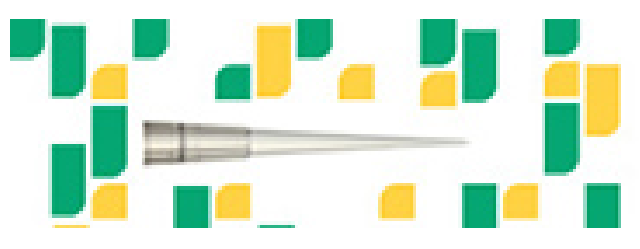

Focused on your science. 